\title{
THE GROWTH TRAP, ECOLOGICAL DEVASTATION, AND THE PROMISE OF GUARANTEED EMPLOYMENT
}

\author{
Jon D. Wisman ${ }^{1}$
}

The "real problem, fundamental yet essentially simple [is] to provide employment for everyone" (Keynes 1980: 267).

"Modern capitalism inflames, through every sense and pore, the hunger for consumption. Satisfying that hunger has become the great palliative of modern society, our counterfeit reward for working irrational hours. Advertisers proclaim a single message: your soul is to be discovered in your shopping" (Skidelsky 2012).

ABSTRACT: The legitimacy of governments in all wealthy countries critically depends upon generating employment. The most widely embraced strategy for doing so is to induce more robust economic growth. Pressure to stimulate growth at practically any cost has been greatly augmented by the current crisis. Tragically, this relentless pursuit of growth is occurring when significant coordinated international responses to the threat of ecological catastrophe are urgently needed. Humanity is institutionally and ideologically trapped in the view that not only is growth necessary for creating employment, it is the panacea for most of our problems. There is a way out of this trap: Guaranteeing employment and where necessary reskilling all capable of work. The immorality of consigning a portion of the workforce to the degradation of unemployment would be eliminated. So too would welfare and its debasement of those able to work. Guaranteed employment would also reduce inequality, the second major force behind the compulsion of growth at any cost. Freed from the social compulsion to pursue growth, humanity could more readily coordinate to address ecological devastation, perhaps the greatest challenge humanity has ever collectively faced.

KEYWORDS: Ideology, employer of last resort, inequality, material progress vision, ecology.

\section{CLASSIFICATION CODES: E24, J21, Q01, Q50.}

Second only to addressing foreign aggressors, unemployment poses the greatest challenge to politicians in power. Their success in dealing with unemployment significantly determines their ability to stay in power. In democracies, political parties across the spectrum, striving to hold onto or acquire office, struggle to convince the electorate that their advocated policies hold the greatest promise of stimulating economic growth and thus reducing unemployment. The continuing contemporary crisis has heightened the pressure to be convincing, and when in power, to show results.

However, this widely embraced strategy of stimulating economic growth to reduce unemployment has meant that other social needs have become demoted, delayed, and frequently depicted as themselves depending upon ever more robust growth. Of these other social needs, that of a sustainable environment has taken on special urgency. The greatest contemporary threat to future human wellbeing is arguably increased environmental degradation. Indeed,

\footnotetext{
${ }^{1}$ Professor of Economics at American University, Washington, D.C.
} 
avoiding devastation of our habitat may be the greatest challenge ever faced by humanity. It has been suggested that our earth has entered a new geological era, the anthropocene. This name captures the pervasive human impact on the whole earth, from the deepest oceans to the edge of space. If this continuing impact were to end the planet's ability to support human life, it would be ecocide.

It is the widely recognized need to reduce unemployment that has, along with excessive inequality, ${ }^{2}$ trapped humanity institutionally and ideologically into a growth trap that has come to pose a severe threat to our collective future. Fortunately there is an escape: Guaranteeing employment and where necessary providing training to all capable of work. The benefits of doing so extend well beyond the ecological threat. It would also eliminate the immorality of consigning a portion of the workforce to the degradation of unemployment. Also eliminated would be welfare and its debasement of those able to work. ${ }^{3}$ Poverty, at least for those able to work, would be eliminated. Inequality would lessen as guaranteed jobs could provide everyone with a living wage, while potential training to enter the private sphere would provide everyone with the necessary human capital to be more productive and thus better paid. By reducing inequality, this second major force locking us into the growth trap would be lessened. Freed from the pursuit of growth at practically any cost, humanity could more readily coordinate to address ecological devastation, arguably the greatest challenge humanity has ever collectively faced.

\section{Earth at Risk}

Over the past decade, scientists have come to a consensus that human activity is dramatically changing the environment, with, should appropriate action not be taken, severe future consequences. The urgency of such action is becoming ever more apparent. This urgency is highlighted by Kissling and Singer: "Many climate experts suggest that we have less than two decades before we reach a point of no return - after that, nothing we can do will prevent climate changes from spiraling into disaster" (2012: B3). The threat is made all that more acute by the fact that the current crisis has decreased focus upon the environment (Eilperin and Craighill 2012: A3).

The output of today's world economy is valued at $\$ 65$ trillion, and over the next two decades, it is expected to double to $\$ 130$ trillion. Whereas global electricity consumption has doubled since 1980, it's expected to double again by 2030 (Cohen 2012: 47), thereby, should adequate measures not be taken, placing enormous further strain on the environment. The oceans - the "lungs of the earth," are 30 percent more acidic today than the pre-industrial level and their acidity is projected to double by the end of the century, posing a severe threat to the sea food web. Cohen reports that "The OECD projected that, by 2050, without more effective energy policies fossil fuels would supply 85 percent of energy demand, thus implying a 50 percent increase in greenhouse gas emissions and worsening urban air pollution" (2012: 47).

\footnotetext{
${ }^{2}$ As Wallich remarked, "Growth is a substitute for equality of income. So long as there is growth there is hope, and that makes large income differentials tolerable" (Wallich 1972; cited in (Wilkinson and Pickett 2009: 221). Inequality is excessive when it exceeds that level necessary to bring forth desired social objectives.

${ }^{3}$ Welfare programs that support the unemployed evolved without an adequate understanding of the central importance of work for social and self-respect, due in part to the fact that much work throughout history was extremely onerous and even demeaning. Nevertheless, virtually any work provides an important degree of social and self-respect.
} 
It was inevitable that humanity would reach a point where its continued activities would pose a severe challenge to the earth's environment. Until recent centuries, human population was small enough and its technology not sufficiently sophisticated that collective human activity could upset global equilibria. It's true that earlier human societies created local ecological devastation, such as deforestation, severe soil erosion, and polluted waterways. They even did so to the point of causing their civilizations to collapse (Diamond 2005). However, their ecologically harmful actions were never before on a sufficient scale to threaten the ecology of the whole earth and thus threaten humanity's very future. But this threat's inevitability is shown by the numbers. Cohen reveals that "Since 1700 human numbers have grown elevenfold, soon to be twelvefold, while economic activity per person has grown twelvefold" (2012: 49). The cumulative impact on the environment has been such that today, this threat is no longer in question among the overwhelming majority of scientists in all fields of ecology.

\section{The Political Threat of Unemployment}

Since its early evolution, capitalism has been plagued by unemployment. Before, workers were fused with the land or tool with which they worked. Unemployment was generated by social dynamics that Marx termed primitive accumulation to characterize the separation of producers from any ownership, control, or command of the means of production. Workers were pushed and pulled from their traditional rights to cultivable land. They were pushed by the enclosure movement and pulled by better conditions in towns. ${ }^{4}$ Rising industrial production increasingly bankrupted independent craftsmen. Producers were being proletarianized, turned into free labor. To survive, they had to locate employers to give them wage work. ${ }^{5}$ Those who failed in doing so would be unemployed, which although functional for capitalists in holding down the wage level, posed a political threat to their state when their numbers grew. ${ }^{6}$ This threat was especially acute during general downturns when unemployment soared.

Although an unemployed class of paupers had always existed, the urbanization that accompanied the unfolding of capitalism concentrated the unemployed in urban centers where they collectively, and often spontaneously, revolted. The extent of this threat was captured early on in mercantilist economic thought, where the necessity of full employment served as a common end to most of the policies they advocated.

Robust industrialization and urbanization during the nineteenth century greatly increased the potential for the working class to threaten violence against the elites' state for redress of their suffering from unemployment, low wages, long hours, dangerous working conditions, poor living conditions and the lack of education for their children. To reduce, and hopefully eliminate this threat, the state - controlled by elites -- began bribing the working class with various

\footnotetext{
${ }^{4}$ A part of the pull is captured in the medieval German saying, "Stadtluft macht frei" (Town air makes you free).

5 Thus, as Marx noted, they were free in a dual sense: free from feudal fetters, but also free of any ownership or control of the means of production. Consequently, "The wage worker..."is compelled to sell himself of his own free will" (1967: 766).

${ }^{6}$ As Adam Smith famously noted,

"Laws and government may be considered in this and indeed in every case as a combination of the rich to oppress the poor, and preserve to themselves the inequality of the goods which would otherwise be soon destroyed by the attacks of the poor, who if not hindered by the government would soon reduce the others to an equality with themselves by open violence" (Smith 1762-63: 208).
} 
benefits and ultimately with the franchise. Both strategies for calming working class revolutionary fervor resulted in a lowering of the amount of surplus that the ruling elites were able to expropriate. ${ }^{7}$ They, of course, knew that this promised to be the consequence, but the alternative of violence and revolution threatened to be far worse. They may have realized, as Muller and Seligson observe, that "the presence of meaningful nonviolent possibilities of influencing the political process will inhibit the ability of revolutionary-minded dissidents to mobilize large followings" (1987: 444). There may also have been some understanding that their superior command of ideology could limit their losses (Wisman and Smith 2011a).

Over the ensuing century, the franchise was extended to ever more citizens, eventually including women and minorities. This "democratization" of the political sphere meant that violence could no longer be readily used against workers, and workers would seek redress of their grievances more frequently in the political sphere than in the streets. Although the elites' wealth and privilege would enable them to continue to exert disproportionate influence over the state, rising or high chronic unemployment would pose an increasingly serious challenge to the elite's ideology and thus prevailing political legitimacy.

This challenge reached its heretofore strongest expression as a consequence of the extreme unemployment and hardship of the Great Depression, resulting in extensive government work projects and welfare measure. In the U.S., it also nurtured the belief that workers had a "right to work" and led to passage of Employment Act of 1946 that explicitly made the federal government responsible for maintain full employment.

\section{The Growth Trap and the Material Progress Vision}

The explicit pursuit of economic growth is quite modern. It is only in the last few centuries that sustainable economic growth has been recognized as even possible. As its possibility dawned, a material progress vision slowly evolved. ${ }^{8}$ Central to this vision is the presumption that not only will economic growth improve material conditions, but that it is the key to the good and just society. Therefore, society should consider economic growth as its highest priority. This has promoted a somewhat exclusive preoccupation with material progress as the key to improved human welfare. Largely neglected have been such essential components of human welfare as more creative and fulfilling work, greater equality in the distribution of opportunity, income and wealth, richer and more supportive communities, and more time for family, friends, and reflection, all of which can be treated as subsidiary issues because maximum material progress is believed to hold the key to a better future. ${ }^{9}$

\footnotetext{
${ }^{7}$ Evidence suggests that the inflection point of the Kuznets curve (where the rising inequality that accompanied early industrialization is reversed) follows upon the reaction of the ruling elites to the threat of violence and revolution (Acemoglu and Robinson 2000).

${ }^{8}$ The material progress ideology has been extensively treated in Wisman (2003).

${ }^{9}$ Keynes gave vivid expression to this vision:

"I see us free, therefore, to return to some of the most sure and certain principles of religion and traditional virtue -- that avarice is a vice, that the exaction of usury is a misdemeanour, and the love of money is detestable, that those walk most truly in the paths of virtue and sane wisdom who take least thought for the morrow. We shall once more value ends above means and prefer the good to the useful. We shall honour those who can teach us how to pluck the hour and the day virtuously and well, the delightful people who are capable of taking direct enjoyment in things, the lilies of the field who toil not, neither do they spin.

But beware! The time for all this is not yet. For at least another hundred years we must pretend to ourselves and to every one that fair is foul and foul is fair; for foul is useful and fair is not. Avarice and usury and precaution must be our gods for a little longer still. For only they can lead us out of the tunnel of
} 
There is a certain irony in the fact that unbridled economic growth now threatens the very future of humanity. It has, of course, been economic growth that has provided humanity with extraordinary success in the primordial struggle with nature to overcome dire material privation. There are many ways to gauge our species' success. Increasing control over nature has permitted population to increase dramatically, from 350 million in 1350 to 1.6 billion in 1900 , to 7.0 billion today. It is projected to peak at about 10.5 billion by 2050 , as population rises by $75-80$ million a year (Cohen 2012: 49). Another measure is the rising number of humans who have come of age without fear of starvation and who live in unprecedented abundance. Ironically, the very fact that so many can be unemployed, suffering unwanted and humiliating leisure, is testimony to the species' success with the material challenge that nature always poses.

The world's poor urgently need the fruits of material progress. However, the material progress vision and the social institutions that support it and are legitimated by it have locked the materially privileged into a never-ending pursuit of ever-greater material output that not only appears to yield no further increases in happiness, but threatens humanity's very future.

The belief that economic growth can decrease unemployment has become a central corollary of the material progress vision. It is, of course, true in the short run. However, although more robust growth typically lowers unemployment, it is never a permanent decline. Thus, in spite of decades of growth, unemployment levels have not trended downward. For instance, in spite of a more than doubling of economic output in the U.S., whereas between 1948 and 1976, the average unemployment rate was 5 percent, between 1977 and 2011, it averaged 6.4 percent. Moreover, policy makers always pull away the punch bowl when unemployment reaches its "natural rate," on the grounds that further stimulation of aggregate demand will only result in inflation. ${ }^{10}$ In this manner, the least privileged are consigned to pay with their unemployment the bill for the overwhelming majority to enjoy price stability - a cruel form of tyranny of the majority!

In today's rich countries, the prevailing view has not only been that economic growth can solve the unemployment problem, but also that it is the appropriate medicine for eliminating insecurity and poverty. Often invoked is John F. Kennedy's metaphor of "a rising tide lifts all boats." However, as Richard Anderson-Connolly aptly puts it:

economic necessity into daylight" (Keynes 1930: 371-72).

Keynes believed that sometime in the early $21^{\text {st }}$ century, we would only need to work 15 hours a week to meet our needs and comforts.

Marx also embraced a material progress vision: "the realm of freedom actually begins only where labor which is determined by necessity and mundane considerations ceases" (1967: 820).

${ }^{10}$ The extreme expression of the concept of a "natural rate" of unemployment was set forth by Edmund Phelps and Milton Friedman. The general message is that whatever the current rate may be, it is likely close to this natural rate and thus nothing, in terms of adjusting aggregate demand, is to be done. The unemployed have freely chosen leisure over income from work, a choice made attractive and more readily possible by unemployment insurance and other social support measures (Lucas and Rapping 1969). Thus, attempts to lower unemployment through measures to augment aggregate demand are doomed to failure. An increase in government spending or a cut in taxes will cause consumers to cut back on spending as their "rational expectations" inform them that their taxes will eventually have to rise to pay off the government debt created by such measures (Barro 1974), a hypothesis that came to be known as "Ricardian equivalence." Stimulative monetary policy will merely raise the price level (Friedman1968). Unemployment can be reduced only by changing the incentive structure facing the unemployed, most importantly, reducing social support programs that permit the unemployed to more readily choose leisure over employment. 
"There is some powerful type of irrationality or deception at work when many people can simultaneously recognize that the problems of insecurity and poverty have shown little or no improvement (and perhaps a worsening) over the last, say forty years, despite the enormous growth in the economy, yet at that same time they believe that economic growth in the future will eliminate problems like insecurity and poverty" (2006: 113).

\section{Guaranteeing Employment}

Although the political right and left differ in the strategies they advance, both focus predominantly on growth for reducing unemployment. The right typically identifies the problem as inadequate incentives stemming from excessive taxation, welfare, regulations, or deficits and national debt that impair confidence. The left usually follows a more traditional Keynesian approach of viewing the problem as due to inadequate demand, and therefore advance calls for stimulative fiscal and monetary policy, although this is at times supplemented by a call for public works expenditures and additional education and training to address structural unemployment. But in spite of their differences, most of the policies for reducing unemployment of both the right and left are focused predominantly upon stimulating growth.

Keynes himself noted the difficulty of achieving full employment by increasing aggregate demand, especially when approaching full employment (Keynes 1964 (1936: 118), and it was for this reason that he was especially concerned that structural unemployment "be treated as something to be handled forcibly and not something to be defeatist about" (Keynes 1980: 357). ${ }^{11}$ Keynes believed that public works must be targeted to those geographic areas the "special" or "distressed areas" where unemployment is highest. Keynes was more concerned with the deficient demand for labor than the inadequate demand for output. However, he stopped short of advocating that employment be guaranteed to all.

But suppose that this bolder step were taken, that directly creating demand for labor were fully implemented? The need to seek growth at practically any cost with its disastrous environmental consequences would be eliminated. Under such a program, employment could be socially guaranteed to everyone willing and able to work (zero involuntary unemployment) by making government the employer of the last resort (ELR). In recent years, a number of economists have advocated just this (e.g., Attali and Champain 2005; Forstater 1998, 1999, 2006; Harvey 1989; Kaboul 2007, 2008; Kregel 1991, 1999; Mitchell and Wray 2005; Palley 2001; Vickrey 1992; Wray 1998a, 1998b, 1999, 2007, Wisman 2010; Wisman and Reksten 2012). ${ }^{12}$

Such a program might work as follows. Government offers employment to anyone who seeks work but would otherwise be without a job. ${ }^{13}$ Government "hires off the bottom" (Mitchell and Wray 2005: 236). The offered wage serves as a price floor, a "living" minimum

\footnotetext{
${ }^{11}$ Most contemporary Keynesians appear to be unaware of Keynes' advocacy of direct job creation. Keynes also noted that to achieve full employment, we are "more in need... of a rightly distributed demand than of greater aggregate demand" (Keynes 1982: 395).

${ }^{12}$ Much of this recent work builds upon Hyman Minsky's development of the ELR concept, beginning in the mid1960s (1965; 1966; 1986).

${ }^{13}$ Or, in technical terms, the program would operate so as to provide an infinitely wage-elastic demand for labor. The price of labor in the program would be set independent of market conditions, and the program would absorb all redundant labor at that price. That is, the market sets the quantity, but not the price.
} 
wage." ${ }^{14}$ Upon losing a job, unemployment insurance could cover a set number of weeks for the individual's job search, at the end of which should a job not have been located, the individual may join the ELR program. ${ }^{15}$ No other form of public support need be available to unemployed able workers. Thus, those who would not accept such employment would be revealing that the offered wage is below their reservation wage (the lowest acceptable wage) and thus they could be considered voluntarily unemployed.

Entering into the ELR program would entail working in a government created job and/or receiving training. The goal would be to keep the entire workforce at work or in training and to move workers into the regular economy as quickly as possible. A job placement component, replacing current employment offices, could facilitate re-entry.

An ELR program would be countercyclical in that it would absorb into a "buffer stock"16 those who are laid off from the private sector during a downturn. Thus it would serve as a powerful automatic stabilizer. Government buys excess labor supply as a buffer stock and releases stock as demand for labor increases. It should be noted that currently unemployment insurance also provides this sort of buffer stock of workers, albeit with the disadvantages of lower incomes and eroding human capital, and without the benefits of maintaining a disciplined work force. ${ }^{17}$ Moreover, in an ELR program, when the private sector expands, it can hire from the government's buffer stock of workers with greater confidence that they possess the appropriate work habits or skills than if it drew from a buffer stock of unemployed workers who frequently have experienced a loss in human capital. The reserve army of the unemployed is replaced by the disciplined and better skilled reserve army of ELR-employed potential employees.

An ELR approach differs radically from the macroeconomic strategy of adequately stimulating aggregate demand such that all unemployed workers find jobs. In an adequate demand approach, reaching full employment is sought indirectly through stimulative fiscal and monetary policy, although actual full employment is never attained. A guaranteed employment program, by contrast, would go directly to the problem by providing all willing and able

\footnotetext{
${ }^{14}$ In the U.S., the low level of the current minimum wage does not provide adequate income for a one-earner family to rise above the official poverty level. Although this state of affairs is widely lamented, it is alleged that the minimum wage cannot be raised without causing further unemployment. An ELR could end-run this scenario. In a transitional period, those losing jobs as the minimum wage is slowly lifted would fall back into the bufferemployment sector where training would raise their skill level such that their productivity would make the higher wages profitable for their future employers (Technically, the value of their marginal product would be raised to equal a higher wage level). Moreover, economists ranging from Adam Smith to Harvey Leibenstein have noted that for both material and psychological reasons, higher wages bring forth greater effort (Leibenstein 1978: 63-64).

15 An ELR program could also be crafted to provide part-time work for those who are only able to find part-time work in the private sector or who can only work part-time due to family responsibilities such as child or parental care.

${ }^{16}$ In Wray’s terms, government serves as “a public-sector-as-buffer-stock-employer” (1998b).

${ }^{17}$ Marx's term for this buffer stock was "reserve army of the unemployed, the function of which was to hold down wages and maintain worker discipline. During early capitalism, the household often provided the function of a buffer stock employer of last resort. This is still true in much of the developing world. Those losing their jobs frequently fall back into some form of informal employment in the household. However, households in modern rich economies can no longer generally provide this function.
} 
unemployed workers with a job. Whereas managing aggregate demand to increase employment is a "trickle down" approach, an ELR is, in Minsky's terms, a "bubble-up" approach "because jobs are offered to workers at the bottom, whose spending then induces firms to increase production of consumer goods - creating new jobs, some of which can be filled by recruiting out of the pool of ELR workers" (Wray 2007: 17).

Any able-bodied worker refusing an ELR job would be voluntarily unemployed and thus not eligible for welfare assistance which would be reserved for those physically or mentally unable to work. An ELR would create full employment regardless of the level of aggregate demand. It is a supply-side as opposed to a demand-side solution to the problem of unemployment.

Any social stigma that working in an ELR might carry would surely be less than being unemployed and dependent upon private charity. Moreover, since the program would serve all unemployed workers, from the least to the most skilled, over time participating in the program might come to be viewed as a normal phase for many workers in a technologically dynamic economy with high worker turnover. With everyone guaranteed a job, no social guilt need be felt for the jobless. Able workers would have no easy excuses for not working.

There are a number of benefits in addition to full employment that would result from an ELR program. First, it would guarantee full employment with the least disruption to markets and macroeconomic stability (Wray 2007: 8). Second, guaranteed employment would enhance productivity in the economy as a whole. The training aspect of an ELR would work towards reducing the structural unemployment resulting from the skills of unemployed workers not matching the skills needed by employers. This skills mismatch is a growing problem as the pace of technological change ever quickens and globalization expands. Also, by removing the threat of unemployment, workers might be less reluctant to leave jobs for which their skill mix is illsuited to search for a better fit (This sort of job search represents an investment in human capital, thereby increasing productivity).

Third, ELR would ultimately eliminate the need for minimum wage legislation. To attract workers, private employers would have to pay a wage equal to or higher than that paid by the government program.

Fourth, ELR could be structured so as to bring about an effective universal health care system. ${ }^{18}$ If government employment were to provide full health care benefits, then private employers would be pressured to offer the same to attract employees. ${ }^{19}$ Indeed, an ELR would marketize a large portion of social welfare.

Fifth, the training component of an ELR would improve the productivity and thus wages of those workers at the lower end of the job spectrum who, although employed most of the time, suffer frequent job loss, interludes of unemployment, and little or no skill accumulation.

\footnotetext{
18. The costs of offering health insurance for ELR workers might not substantially add to government spending, as employed workers need less medical attention than do the unemployed and spending on Medicaid and Medicare would be reduced.

${ }^{19}$ Critics claim that if wages are set too high in ELR, especially with healthcare benefits, then workers might be drawn out of the private sector, or held there only by inflationary wages. Proponents of an ELR counter that the one-time increase in prices following the introduction of an ELR would draw workers out of the program and prices would then stabilize (Palley 2001: 3).
} 
Sixth, an ELR would significantly reduce inequality as its living wage would eliminate poverty for able workers and its training component would increase skill levels and therefore wage levels.

Finally, as Vickrey points out, "Under conditions of full employment, trade-balance deficits become not a matter of exporting jobs, but of importing capital" (1992: 342).

There is likelihood that the introduction of an ELR program would initially be inflationary, especially with ELR wages set above minimum wages. Its introduction would also increase aggregate demand if the increase in government spending were not offset by cuts in other government spending or increases in taxes. ${ }^{20}$ However, Mitchell and Wray (2005; Wray 1998) argue that after its introduction, it would be anti-inflationary, or failing that, at least noninflationary. But would not guaranteed employment embolden workers to demand higher wages? Wray counters this possibility by noting that

"...while workers have the alternative of ELR jobs, employers have the opportunity of hiring from the ELR pool. Thus if the wage demands of workers in the private sector exceed by too great a margin the employer's calculation of their productivity, the alternative is to obtain ELR workers at a mark-up over the ELR wage. This will help to offset any wage pressures caused by elimination of the fear of unemployment" (2007: $18) .^{21}$

Moreover, workers within the program would presumably come to possess the skills needed in the private sector. Or at a minimum, workers would be disciplined. If such workers were to be more productive, this would put downward pressure on prices. Worker productivity might also be enhanced if increased job turnover improved job fit. Upward wage pressures might be lessened in an inflationary period as employers could readily hire workers from the buffer stock who are obviously willing to work, are disciplined and perhaps well-trained. In an expansion, as workers are pulled from the buffer stock into the private sector, spending in the ELR program would decrease, countering some of the inflationary pressures of the expansion. That is, even in an expansion, labor markets would be loose. ${ }^{22}$ Mitchell and Wray also speculate that the anti-inflationary character of ELR might end the need for restrictive monetary policy to address inflationary pressures. After its introduction, no further inflationary pressure should result and the "natural rate of unemployment" becomes zero (Mitchell and Wray 2005: 4).

Several economists have estimated the likely cost of an ELR program (Attali Champain 2005; Godin 2012; Gordon 1997; Wray 1997, 1998, 2011; Gordon 1997). A more extensive study by Kaboub estimates that a comprehensive and very generous ELR program, with a threetier skill based wage scale, "could employ 23.4 million people for less than $\$ 600$ billion annually, or less than $4 \%$ of GDP, ${ }^{23}$ with the added benefit of increasing GDP by nearly one

\footnotetext{
${ }^{20}$ Malcolm Sawyer (2003) has argued that inflationary pressures would continue to haunt ELR even after its introduction. For a refutation, see Fullwiler (2007); Mitchell and Wray 2005.

${ }^{21}$ “This is [according to Wray] the primary 'price stabilization' feature of the ELR program” (1998: 543).

22 "Further, [as Wray points out] reduction or elimination of employment taxes related to the unemployment insurance program will also attenuate pressure on prices, as will reduction of private and social costs of unemployment (for example, reduction of crime will lower business costs)" (1998: 544).

${ }^{23}$ This corresponds to the costs estimated by Attali and Champain for France. They noted that in 2004, a full count of unemployment in France came to about 19 percent of the workforce and that France spent 4.2 percent of GDP on
} 
trillion dollars per year" (2012: 109). His 23.4 million people include "the 12.7 million who are officially unemployed, the 2.6 million marginally attached to the labor force and the 8.1 million involuntary part-time workers" (2012: 105). His hourly wage scale would be $\$ 21$ for skilled workers, $\$ 18$ for semi-skilled, and $\$ 15$ for unskilled, all with a $\$ 10,000$ annual benefits package. A training program for such a program would, of course, considerably increase costs.

Fully forecasting the long run costs and benefits of an ELR program, especially one with a sophisticated reskilling component, would be difficult. It would entail estimating the value produced by ELR workers, the enhanced productivity of ELR-trained workers when they enter the non-ELR work sphere, the resulting increase in tax revenues and the decrease in social costs currently resulting from unemployment. Unemployment benefits would disappear and social support costs would decline. Unemployment-generated health costs borne by Medicaid would be practically eliminated.

For the unemployed who are absorbed into an ELR, there are also "non-pecuniary" costs that would be eliminated. It has have been estimated these costs drastically outweigh the monetary and consumption costs of not possessing a job (Winkelmann and Winkelmann 1998: 1). Such costs include poorer health, mental distress, alcohol abuse, lowered social status, lowered self-esteem, marital instability, proneness to violence and crime, increased vulnerability to suicide, loss of networking opportunities, lower levels of personal fulfillment.

Many of the personal costs of unemployment also have a public dimension. Studies have found a correlation between increased unemployment and increased criminal activity. ${ }^{24}$ Unemployment-generated crime would disappear. Grogger (1998) and Gould (2002) find that youth criminal activity positively correlates with the unemployment rate. Unemployment fuels prejudice against minorities and immigrants (Sen 1997). Adolescents with unemployed parents do less well in school, and those who attempt suicide are more likely to have an unemployed father than adolescents who do not attempt suicide (Storm 2003: 401).

An ELR program could be decentralized so as to better meet local needs. For instance, states could receive an ELR budget from the Federal government relative to their rate of unemployment (Wray 1999: 485). If the program were to be administered by states or even smaller political jurisdictions, then the ELR wage could be set in terms of the local cost of living. Further, the local ELR wage could be set lower the higher the percent of the local labor force absorbed into the program, so as to preserve incentives for mobility. ${ }^{25}$

An ELR program would also face the challenge of employing workers in domains that do not directly compete with the private sector or with current public sector jobs. Domains that come to mind include programs for assisting the ever-expanding elderly population, tutoring less-privileged children, day care, and improving the quality of the public space. The latter might include burying electric lines, and providing flowers, benches, statuary, and fountains

\footnotetext{
labor and unemployment support programs. They estimated that an ELR for France would in the end cost about the same amount, or four percent of GDP (2005: 6-7).

${ }^{24}$ Surveys of this research are provided by Cameron 1988; Freeman 1996; Raphael and Winter-Ebmer 2001). Currently, the U.S. spends $\$ 60$ billion annual on its prison system, incarcerating 2.3 million Americans (Moyers 2012).

${ }^{25}$ For a discussion of different ELR program designs, see Wray 2007.
} 
along streets and in parks. ${ }^{26}$ But one of the most promising uses of ELR workers would be to employ them in "green jobs" that reduce the likelihood that our species commits ecocide!

In addition to being expensive, at the outset, such a program would likely be inefficient. However, with time, its efficiency should improve in the nature and quality of work performed, in its training component, and in its ability to help its participants locate employment. Attitudes towards such a program would also likely change. Just as the public school system is seen as a necessary social institution for economic dynamism and fairness, so too might be an ELR program.

\section{Reducing Inequality}

Because economic growth makes inequality less intolerable, it is the second principal force pressuring political systems to pursue economic growth at practically any cost and thus a principal impediment to addressing the urgent challenge of environmental devastation. ${ }^{27}$

Guaranteeing employment to all able-bodied workers would constitute a major step toward reducing inequality. This would especially be true with an ELR wage set to provide a living wage. As noted above, poverty would be eliminated for all able to work. An ELR would also reduce inequality by augmenting the human capital of the least privileged, those whom current social conditions and the education system cheat out of an adequate preparation for work life. Guaranteeing employment and adequate skills to enter the private labor market could be expected to provide cumulative benefits as poverty and dysfunctional neighborhoods disappear. Children would grow up in families where parental employment offers social and personal respect, and in neighborhoods where the able are gainfully employed. The role models would be adults with jobs as opposed to hustlers and often violent criminals.

Inequality severely hinders societies' struggle to address ecological devastation for two major reasons. First, the wealthy benefit more financially from pollution than the less well off and they can shield themselves from many of pollution's negative consequences (Princen 2002), whereas the least privileged most suffer pollution (Boyce 2007; Bullard 2000; Szasz and Meuser 1997). Second, the greater inequality, the higher the consumption standards set by the wealthy, putting in motion a more robust form of conspicuous consumption among them and those below struggling to preserve their relative social status. But as Bauman has put it, "In the consumer race the finishing line always moves faster than the fastest of runners" $(2000,72)$.

The benefits to the wealthy of not addressing environmental destruction are twofold. First, much pollution is the consequence of negative externalities, meaning that some production costs to society are not included in the market price of output. This means that the social costs of production exceed the private costs as captured in market prices, and thus because the rich consume more per capita than do the less well off, they proportionately benefit more from pollution. In the U.S., 38.5 percent of total consumer spending is done by the wealthiest 20 percent of the population (Consumer Expenditure Survey 2008). In 2007, the wealthiest 10 percent held 45.9 percent of total home equity and 25.5 percent of the value of vehicles (Gilbert 2011, 91). Wilkinson and Pickett report that "The carbon emissions caused by the consumption

\footnotetext{
${ }^{26}$ Wray offers an extensive list of jobs that might be undertaken by an ELR program (1997: 15-16). He also suggests that in the U.S., an ELR program might fund “...qualifying non-governmental non-profit organizations, such as Americorps, VISTA, the Student Community Service Program, the National Senior Service Corps, the Peace Corps, the National Health Service Corps, school districts, and Meals on Wheels..." (2007: 11). Wray notes that "Use of existing groups would help minimize start-up costs and duplication of administration costs" (1997: 14).

${ }^{27}$ The impact of inequality on the environment is extensively treated in Wisman $2011 \mathrm{~b}$.
} 
of a rich person may be ten times as high as the consumption of a poorer person in the same society" $(2009,218)$.

The second reason the wealthy gain more from pollution is because they hold greater ownership claim to the industries that have higher profits because they can pass costs off onto the environment. In 2007, for example, the wealthiest one percent of Americans owned 49.3 percent of stocks and mutual funds, the richest 10 percent, 89.4 percent. The remaining 90 percent owned only 10.6 percent (Wolff 2010: Table 9: 52).

The wealthy elite that most benefits from continuing environmental destruction and least suffers its consequences, understandably gravitates spontaneously toward political and economic doctrines that are supportive of their self-interests. Their disproportionate political power impedes adequately significant policy responses to the environmental threat. ${ }^{28}$

The second major way in which inequality impedes societies' ability to address the threat of ecological devastation stems from a dynamic analyzed long ago by Thorstein Veblen (1899). In highly unequal societies where the potential for vertical social mobility is presumed to be high, and especially where inequality is increasing, status competition augments consumption. Where vertical mobility is believed to be highly fluid, individuals internalize responsibility for their successes or failures. This places considerable pressure on people to demonstrate high status. To the extent they succeed in doing so, they appear to possess the virtues of hard work. However, how hard one works is generally not directly observable in modern wealthy economies. What more readily catches attention is how much one can consume, which can stand more or less as a proxy for how hard one has worked. The more one consumes, the harder one must have worked. The greater the degree of inequality, the harder families must struggle to certify their social standing. Inequality, by setting the material goal at the level of society's wealthiest families encourages families below that seek social and self respect to emulate them. Thus, not surprisingly, in the U.S., as inequality increased over the three decades leading up to the crisis, household saving plummeted, they went deeper into debt, and they worked longer hours (Wisman 2009).

Further, a considerable amount of this status-driven consumption occurs in highly visible luxury goods such as huge homes, powerful automobiles, and foreign travel that have considerable negative environmental impact. ${ }^{29}$ That is, the general thrust of status competition biases consumption toward those goods that are highly polluting in their production and

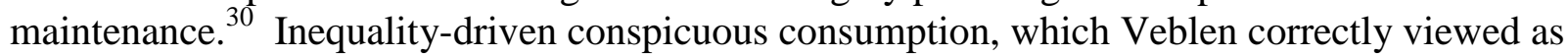
"indefinitely expansible" (1899: 111), races humanity toward catastrophe. Status competition

\footnotetext{
${ }^{28}$ Kevin Phillips contends that American "politics is increasingly dominated by people in the upper-income brackets" $(2002,15)$. For political scientist Robert Hunter Wade, this domination is by extremely few Americans: "The people who make the economic and political decisions that matter are concentrated in the top 1 percent of the U.S. household income distribution" $(2004,71)$.

${ }^{29}$ Wilkinson and Pickett report that "research confirms that the tendency to look for goods which confer status and prestige is indeed stronger for things which are more visible to others" (2009: 225). The super-rich households are ever in competition with each other for the very pinnacle of status, dramatically increasing the consumption of extremely expensive goods and services (private jets, mansions, Hirschian positional goods, etc.). As Bauman has put it, "In the consumer race the finishing line always moves faster than the fastest of runners" $(2000,72)$.

${ }^{30}$ Although some degree of status is sought by "going green" in certain visible consumption domains such as electric or hybrid automobiles, and solar panels on homes, this pales alongside more environmental destructive status-driven consumption.
} 
also biases consumption in favor of private goods as opposed to public ones such as quality of the environment or public transportation that reduce strains on the environment.

Considerable inequality reduces the potential for work to serve as an adequate medium for achieving fulfillment. Because inequality propels households toward consumption to maintain their social standing, where a trade-off exists between work quality and income, inequality encourages workers to choose the latter. The labor market reinforces this tendency. As Lane notes, "In the labor market where workers are free to choose, there is poor information on quality of work life, the default values of money are strong, family benefits flow from money but not for intrinsic satisfaction" $(1991,406)$. Thus, work becomes more biased toward a means to the end of higher consumption and away from its potential for serving as an outlet for sociality, self-expression, and creativity. ${ }^{31}$

Inequality re-enforces the material progress vision, the ideology that economic growth should be society's foremost goal because it delivers an ever higher standard of material well being. However, a substantial body of work in psychology, especially in what has come to be called "happiness research," finds that above a fairly low threshold, subjective well-being does not correlate with higher incomes and thus higher levels of consumption. Although it has been found that average levels of satisfaction are considerably lower in very poor countries than in rich ones, after a certain income level has been attained, further increases in income do not seem related to higher levels of subjective well-being (Diener and Diener 1995; Veenhoven 1993; Easterlin 2001, 2002). In terms of income and consumption, what appears to be important is ones relative position. This importance of relative income standing has been confirmed in a study by Solnick and Hemenway (1998) that finds that when presented with the question of whether they would prefer to live less-well-off in a rich society or near the top in a poorer society, fifty percent claimed they would give up half their real income to live in a society where they were better off than most others.

This preoccupation with economic growth and material accumulation debases and conceals from view the two interrelated domains of work and community in which fulfillment and self-esteem are more richly nourished. Nevertheless, at some level these domains continue to be recognized as important. In their extensive interviews of Americans, Bellah et. al. found them in agreement that

"...two of the most basic components of a good life are success in ones work and the joy that comes from serving ones community. And they would also tend to agree that the two are so closely intertwined that a person cannot usually have the one without having the other" $(1985,196)$.

\section{Work}

Research has found that above a certain material threshold, it is in the realm of work that well-being is most readily achieved. As Robert Lane has put it, "It is in work, not in consumption and, as research reports show, not even in leisure, where most people engage in the activities that they find most satisfying, where they learn to cope with their human and natural environments, and where they learn about themselves" (1991: 235).

Having a job - working - is very important for self-identity. A World Values Survey found that "only 22 percent of respondents agreed that a job is just a way of earning money, and

\footnotetext{
${ }^{31}$ Psychologist Csikszentmihalyi claims that "....in our culture the aversion to work is so ingrained that even though it provides the bulk of the most complex and gratifying experiences, people still prefer having more free time, although a great deal of free time is in fact relatively boring and depressing" (1993: 202).
} 
63 percent said that they would enjoy having a paying job even if they did not need the money" (Alesina, Glaeser, and Sacerdote 2002, 239). Diener and Seligman, in reviewing the literature on the economic psychology on well-being, find two of the six major factors to be: Living in a democratic and stable society that provides material well-being, and having rewarding and engaging work. ${ }^{32}$

Within good workplaces, work provides a ready medium in which self-esteem can flourish. In work we contribute to society's wealth (as opposed to drawing upon society's wealth in consumption), and thus we have grounds for a sense that we are participating in achieving society's well-being. Workers who are fairly autonomous and possess a degree of control over the work process achieve a sense of accomplishment. Lane relates that "There is evidence that exercise of discretion on the job, which is not so much a right as a requirement of complex tasks, has more substantial effect on self-esteem than any exercise of familiar political rights has ever had" (Lane 1991, 198). Moreover, on the job, workers can aid our fellow workers and bask in their appreciation of our assistance and our skills. Self-esteem is highly dependent upon social esteem.

By guaranteeing jobs and training, an ELR would expand the workforce as it would eliminate the uncertainty as to whether work could be found. It would thereby expand the potential for people to seek fulfillment in work, especially as their skill levels increase, as opposed to having to find it in consumption, and thereby reducing environmental strain. ${ }^{33}$

\section{Community}

The debasement of work and the elevation of consumption as the domain in which selfworth and identify are sought work against community. ${ }^{34}$ Inequality reduces the potential for community because, as Irvin reports, it reduces social capital: "Where there is more income inequality, poorer people are more likely to feel out of place participating in community groups, more likely to feel ill at ease and to think that they will make fools of themselves and be looked down upon" $(2007,15){ }^{35}$

An important component of social capital is trust. The European and World Values Survey has found that trust is higher in countries with less inequality. The General Social Survey done by the U.S. government has also found that trust is higher in states with less inequality (reported in Wilkinson and Pickett 2009: 53-54).

\footnotetext{
${ }^{32}$ The other four are: to have supportive friends and family, to be reasonably healthy and have treatment available in case of health problems, to have important goals related to ones values, and to have a philosophy or religion that provides guidance, purpose, and meaning to one's life $(2004,25)$.

${ }^{33}$ Lane notes that "Unlike commodities, skills have rising marginal utilities" (2000: 308).

${ }^{34}$ Bauman claims that "Producers can fulfill their vocation only collectively; production is a collective endeavour, it presumes the division of tasks, cooperation of actors and coordination of their activities...Consumers are just the opposite. Consumption is a thoroughly individual, solitary and, in the end, lonely activity.... The activity of consumption ... [renders] all efforts of bonding impotent in overcoming the endemic loneliness of the consuming act. Consumers are alone even when they act together" (Bauman 2005, 30; 31). Although consumption is perhaps not as lonely as Bauman imagines (friends often shop together and enjoy sharing their purchases), it does not offer the same potential for gaining social- and self-respect as does work.

${ }^{35}$ Jargowsky provides further evidence supporting Christopher Lasch's thesis (1995) that due to greater inequality, Americans are becoming increasingly segregated by income and privilege and that this segregation is working against racial and ethnic harmony (1997).
} 
Wilkinson and Pickett report that "In the USA, trust has fallen from a high of 60 percent in 1960, to a low of less than 40 percent by 2004" $(2009,54)$. As trust fell, more gated communities sprang up, sales of home security systems grew, and sales of SUVs, -- tanks for the hostile public sphere - soared. Even the adventuresome youth practice of hitchhiking all but disappeared.

In their survey of studies on trust, Wilkinson and Pickett find that "With greater inequality, people are less caring of one another, there is less mutuality in relationships, people have to fend for themselves and get what they can - so, inevitably, there is less trust.... High levels of trust mean that people feel secure, they have less to worry about, they see others as cooperative rather than competitive" $(2009,56 ; 57)$. Planet Ark Environmental Foundation has found that more equal societies tend to have greater social cohesiveness and public spiritedness, resulting in greater recycling of waste materials (Planet Ark 2004).

Also working against community is the fact that greater inequality generates more criminal activity. Kelly finds that inequality has "a strong and robust impact on violent crime, with an elasticity above $0.5 "(2000,530)$. This research is supported by that of Fajnzylber et. al. who find in a study of 39 countries between 1965 and 1995 that violent crime rates and inequality were positively correlated "within countries and, particularly, between countries, and this correlation reflects causation from inequality to crime rates, even after controlling for other crime determinants" $(2002,1)$.

The belief in the potential for fluid mobility that came with the breaking of inherited class power promised more equality of opportunity. However, where inequality is great, an extreme adherence to this belief can work against a sense of community. This appears to be the case in the U.S. with its strong belief in the possibility of vertical mobility and its high degree of inequality. ${ }^{36}$ Individuals not only readily take credit for their economic successes, but also readily view the less fortunate as responsible for their economic failures. Alesina, Glaeser, and Sacerdote report that the World Values Survey found that 71 percent of Americans versus 40 percent of Europeans believe that the poor could work their way out of poverty. "...54 percent of Europeans believe that the poor are unlucky, whereas only 30 percent of Americans share that belief." And "Sixty percent of American respondents, but only 26 percent of Europeans say that the poor are lazy" $(2001,237 ; 242 ; 243)$. These differences may also help explain Americans' stronger embrace of laissez-faire political ideology (see also, Lipset 1998). Alesina and La Ferrara find that in the U.S., those individuals who believe they will experience future income growth more readily oppose measures that would redistribute income in favor of the less well-off (2001).

In devaluing the potential for work and community to provide social certification and personal fulfillment, and shifting attention to consumption, inequality feeds a material progress vision, the view that ever-greater material abundance is the key to happiness. It is this inequality and the belief that growth is necessary to generate employment that threaten humanity with its possible extinction.

\section{Sane Growth and Human Progress}

\footnotetext{
36 Although the general view in the U.S. is that America is the exceptional land of opportunity, This belief is apparently no longer backed by fact. An OECD study (d'Addio 2007) finds upward mobility between generations to be lower in the U.S. than in Canada, Sweden, Germany, Spain, Denmark, Austria, Norway, Finland, and France. Further evidence that the U.S. is no longer the exceptional land of great equality of opportunity is provided by a number of other studies (Bradbury and Katz 2002: 4; Hertz 2007; Mishel, Bernstein, and Allegretto 2009; Mazumder 2005; Solon 1992).
} 
No longer being compelled to seek growth so as to reduce unemployment and make inequality tolerable would by no means end growth. ${ }^{37}$ The Congressional Budget Office estimates that if the unemployed could be employed, the U.S. economy could be producing an extra $\$ 900$ billion worth of goods and services per year. With a better educated and skilled labor force, growth would likely be more robust. However, society would be freed from having to sacrifice other social goals so as to achieve growth, and it would be freed to steer growth in an ecologically benign manner. Indeed, growth could be steered so as to reduce environmental stress.

Moreover, in one manner or another, much greater attention needs to be given to educating workers and keeping their skills up to date. In pre-modern agricultural society, practically all education and training occurred in the household and on the job. Only a thin elite received formal education. With the rise and expansion of capitalism, human capital became more important and a demand for publically provided education came forth, first from a rising middle class, and then from the working class. However, relatively little progress was made before the end of the nineteenth century in extending educational opportunity to the working class until it became capable of threatening the elites' state with violence. Thereafter, significant advances were made during periods when workers retained relatively more political power. Guaranteed schooling expanded to a full 12 years, and eventually even low-cost post-secondary schooling greatly expanded.

However, the erosion of working class power in the U.S. since the mid-1970s has not only dramatically increased inequality, but also slowed the improvement of educational opportunities for their children. Meanwhile, the pace of change within capitalist societies, driven by technological change and globalization, has been ever increasing such that the formal education that society provides to some of its future workers is not adequate for the demands of the job market. Further, in an ever-more-complex economy, the training many receive when young is not adequate for their full work lives. Most will need continual retraining. While much of this training has been and will continue to be on the job, some workers will lose their jobs, and for lack of necessary skills not find comparable new ones. Although publicly provided formal schooling might provide some of the necessary re-skilling, some workers who perform poorly in school settings learn well when training is part of their jobs.

Thus beyond helping humanity escape the growth trap with its disastrous consequences for the environment, an ELR program is necessary for maintaining adequate skills and full employment in an increasingly complex workplace. ${ }^{38}$ Moreover, to the extent that unemployment is structural, policies to stimulate the economy threaten to unleash inflationary pressures. Not only would an ELR eliminate the need to stimulate the economy to reduce unemployment, it would also promise to reduce the skills mismatch.

\section{Final Reflections}

The attainment of full employment would not be a full panacea for the ecological threat. But it would eliminate the major force focusing state policy on generating growth. It would also reduce inequality and thereby enable individuals to more readily find social certification of their

\footnotetext{
${ }^{37}$ Benjamin Friedman contends that some growth may be essential for a functional political system because during periods of stagnation, political positions harden and extreme parties gain adherents (Friedman 2011).

${ }^{38}$ For a fuller exposition of the manner in which an ELR could maintain an adequately skilled workforce, see Wisman and Reksten 2012).
} 
value through work and community. Guaranteed jobs and reduced inequality would permit society to better focus on reducing the centrality of consumption as the foremost human pursuit. Further, "green jobs" could be made an important focus for ELR jobs and training. ${ }^{39}$

But if guaranteeing employment and reskilling is such a good idea, why have political parties supporting the interests of workers not made it a central part of their platforms? It is understandable that prior to the democratization of the franchise, advocates for the working class would be reluctant to propose guaranteed employment. In fact, something of that sort had existed at times, as Hobsbawn put it in, "the jail-like workhouse, [that] forcibly separated husbands, wives and children in order to punish the poor for their destitution, and discourage them from the dangerous temptation of procreating further paupers" (1968: 69-70). Also, many jobs were brutal and dehumanizing.

There was in fact a push for guarantee employment during the 1930s in the U.S. that resulted in three job creation programs employing 1.4 to 4.4 million people each month. There was also an unsuccessful attempt to make "Employment Assurance" a part of the Social Security Act. What is seldom realized is that during World War Two, the U.S. government instituted an ELR, albeit with such intention when nine million men and women were put in military uniform. In 1943, a "New Bill of Rights" was proposed, although not adopted, that would have entailed the "formal acceptance by the Federal Government of responsibility for insuring jobs at decent pay to all those able to work regardless of whether or not they can pass a means test" (cited in Rose 2012). In his 1944 State of the Union address, Roosevelt advocated an "economic bill of rights" that would include the "right to a useful and remunerative job" and the "right to earn enough to provide adequate food and clothing, and recreation" (U.S. Senate. 1960: 1-2; cited in Rose 2012).

Finally, there is something morally amiss in a rich economy that leaves a portion of its workforce unemployed and without adequate skills to readily find employment. No matter the unemployment rate, it is morally wrong for an over-whelming majority of the population to condemn a portion of society - usually the least privileged - to a life of unemployment and under-employment. The personal costs that these unfortunates must suffer are far too high. ${ }^{40}$ As noted earlier, it constitutes a tyranny of the overwhelming majority. It sacrifices those who are generally the poorest to what is perceived (mistakenly!) to be in the best interests of the society. There is, then, a moral imperative, as well as social rationality, to guaranteeing employment and re-training for the full workforce (Wisman 2010).

\section{REFERENCES}

Acemoglu, Daron, and James A. Robinson. 2000. "Why Did the West Extend the Franchise? Democracy, Inequality, and Growth in Historical Perspective," The Quarterly Journal of Economics: 1167-99.

\footnotetext{
${ }^{39}$ Forstater provides the following examples of what a Green Jobs Corps might undertake: "community and industrial recycling, improved insulation for residential and commercial structures, carpooling, rooftop gardening and urban landscaping, solar energy applied to public infrastructure (e.g., streetlights, schools, construction warning signs, billboards), monitoring and enforcement, environmental education, and research support (2006: 64).

40 Avner Offer notes that "The strongest determinant of low life satisfaction is absence of social connection, particularly unemployment and separation..." (2007: 7). In his new book, professor of psychiatry, James Gilligan claims that the inability to find a job is the foremost driver of shame and worthlessness (2011).
} 
Alesina, Alberto, and Eliana La Ferrara. 2001. "Preferences for Redistribution in the Land of Opportunities." Working Paper 8267. Cambridge, Mass.: National Bureau of Economic Research.

Alesina, Alberto, Ed Glaeser, and Bruce Sacerdote. 2002."Why Doesn't the United States Have a European-Style Welfare State?" Brookings Papers on Economic Activity: 187-277.

Anderson-Connolly, Richard. 2006. "The Problem with Growth as the Solution," Challenge, 49 (1), January/February, 90-118.

Attali, Jacques, and Vincent Champain. 2005. Changer le paradigm pour supprimer le chômage. Paris: Foundation Jean-Juares, November.

http://juliette.nfrance.com/ ju16656/Supprimer/texte.pdf

Barro, Robert J. 1974. “Are Government Bonds Net Wealth?” Journal of Political Economy, 82, 1095-1117.

Bauman, Zygmunt. 2000. Liquid Modernity. Malden, MA: Blackwell.

Bauman, Zygmunt. 2005. Work, Cosumerism and the New Poor. $2^{\text {nd }}$ Ed. New York: Open University Press.

Bellah, Robert N., Richard Madsen, William M. Sullivan, Ann Swindler, and Steven M. Tipton. 1985. Habits of the Heart: Individualism and Commitment in American Life. New York: Perennial Library.

Boyce, James K. 2007. "Inequality and Environmental Protection," in Inequality, Collective Action, and Environmental Sustainability, Jean-Marie Baland, Pranab Bardhan, and Samuel Bowles, eds. Princeton: Princeton University Press: 314-48.

Bradbury, Katharine and Jane Katz. 2002. "Are Lifetime Incomes Growing More Unequal? Looking at New Evidence on Family Income Mobility." Regional Review, Q4, Federal Reserve Bank Boston: 3-5. http://www.bos.frb.org/economic/nerr/rr2002/q4/issues.pdf

Bullard, Robert D. and Glenn S. Johnson. 2000. "Environmental Justice: Grassroots Activism and Its Impact on Public Policy Decision Making," Journal of Social Issues, 56, 3: 555-78.

Cameron, Samuel. 1988. "The Economics of Crime and Deterrence: A Survey of Theory and Evidence," Kyklos, 41 (2): 301-23.

Chapin, Stuart F. And Julius A. Jahn. 1940. "The Advantages of Work Relief over Direct Relief in Maintaining Morale in St. Paul in 1939," The American Journal of Sociology, 46 (1): 13-22

Cohen, Joel E. 2012. "What will it take to Save the Earth?" The New York Review, April 26: 4749. 
Csikszentmihalyi, M. 1993. The Evolving Self. New York: HarperCollins Publishers, Inc.

d'Addio, Anna Cristina. 2007. "International Transmission of Disadvantage: Mobility or Immobility across Generations? A Review of the Evidence for OECD Countries," OECD Social, Employment and Migration Working Papers, no. 52, Paris http://www.oecd.org/els/workingpapers).

Diamond, Jared. 2005. Collapse: How Societies Choose to Fail or Succeed. New York: Viking.

Diener, Ed, and Carol Diener. 1995. "Factors Predicting the Subjective Well-Being of Nations," Journal of Personality and Social Psychology, 59: 851-64.

Diener, Ed, and Martin Seligman. 2004. "Beyond Money. Toward an Economy of Well-Being," Psychological Science in the Public Interest, 5, 1: 1-31.

Easterlin, Richard. 2001. "Income and Happiness: Toward a Unified Theory," Economic Journal, 111, 473: 465-84.

Easterlin, Richard. 2002. Happiness in Economics. Cheltenham: Edward Elgar.

Fajnzylber, Pablo, Daniel Lederman and Norman , Loayza. 2001. "Inequality and Violent Crime," Journal of Law and Economics, 45: 1-45.

Eilperin, Juliet and Peyton M. Craighill. 2012. "Concern about the Climate Declines," The Washington Post, July 3: A3.

Forstater, Mathew. 1998. "Flexible Full Employment: Structural Implications of Discretionary Public Sector Employment," Journal of Economic Issues, 32 (2): 557-63.

Forstater, Mathew, 1999. "Institutional Approaches to Full-Employment Policies," Journal of Economic Issues, 32 (4): 1135-40.

Forstater, Mathew. 2006. "Green Jobs: Public Service Employment and Environmental Sustainability,” Challenge, 49 (4), July/August: 58-72.

Freeman, Richard B. 1996. "Why Do So Many Young American Men Commit Crimes and What Might We Do About It?" Journal of Economic Perspectives, 10 (1): 25-42.

Friedman, Benjamin. 2011. "The No-Growth Trap," The National Interest, 11, November/December: 36-43.

Friedman, Milton. 1968. "The Role of Monetary Policy,” American Economic Review, 58 (1), $1-17$. 
Gilbert, Dennis. 2011. The American Class Structure in an Age of Growing Inequality. $8^{\text {th }}$ Ed. Los Angeles: Sage.

Gilligan, James. 2011. Why Some Politicians are More Dangerous than Others. New York: Polity Books.

Godin, Antoine. 2012. “Guaranteed Green Jobs: Sustainable Full Employment,” Levy Economics Institute, Working Paper No. 722, May.

Gordon, Wendell. 1997. "Job Assurance - The Job Guarantee Revisited," Journal of Economic Issues, 31 (3): 826-34.

Gould, Eric D., Bruce Weinberg, and David B. Mustard. 2002. "Crime Rates and Local Labor Market Opportunities in the United States: 1979-1997," Review of Economics and Statistics, 84 (1), February: 45-61.

Grogger, Jeff. 1998. "Market Wages and Youth Crime,” Journal of Labor Economics, 16 (4): 756-91.

Harvey, Philip. 1989. Securing the Right to Employment. Princeton, New Jersey: Princeton University Press.

Hertz, Tom. 2007. "Trends in the Intergenerational Elasticity of Family Income in the United States," Industrial Relations, 46 (1): 22-50.

Hobsbawn, E. J. 1968. Industry and Empire: An Economic History of Britain since 1750. London: Weidenfield and Nicholson.

Huber, Evelyne, Dietrich Rueschemeyer, and John D. Stephens. 1993. "The Impact of Economic Development on Democracy.” Journal of Economic Perspectives, 7 (3): 71-85.

Irvin, George. 2007. "Growing Inequality in the Neo-liberal Heartland," Post-Autistic Economics Review, 43: 1-23.

Jargowsky, Paul. 1997. Poverty and Place: Ghettos, Barrios, and the American City. New York: Russell Sage.

Kaboub, Fadhel. 2007. "Institutional Adjustment for Full Employment," Journal of Economic Issues, 41(2): 495-502.

Kaboub, Fadhel. 2008. "Elements of a Radical Counter-Movement to Neoliberalism: Employment-Led Development," Review of Radical Political Economics, 40(3): 220227. 
Kaboub, Fadhel. 2012. "The Low Cost of Full Employment in the United States," in The Job Guarantee: Toward True Full Employment, Matthew Forstater and Michael Murray, eds. New York: Palgrave (forthcoming).

Kelly, Morgan. 2000. "Inequality and Crime," The Review of Economics and Statistics, 84, 2: 530-39.

Keynes, John Maynard. (1930) Essays in Persuasion. New York: Harcourt, Brace, and Co.

Keynes, John Maynard. 1980. Activities 1940-46. Shaping the Post-War World: Employment and Commodities. Vol. XXVII of Collected Works, D. Moggridge (ed.). London: UK: Macmillan.

Keynes, John Maynard. 1936. The General Theory of Employment, Interest, and Money. New York: Harcourt-Brace and World, 1964.

Keynes, John Maynard. 1982. Activities 1931-39. World Crises and Policies in Britain and America. Vol. XXI of Collected Works, D. Moggridge (ed.). London: Macmillan.

Kissling, Frances, and Peter Singer. 2012. "To Fix the Climate, Take Meat off the Menu," The Washington Post, June 17: B3.

Kregel, Jan A. 1991. "Is Keynesian Full Employment Policy for 'Top Countries' Only?" The Art of Full Employment: Unemployment Policy in Open Economies. C. De Neubourg, ed. Amsterdam: North-Holland.

Kregel, Jan A. 1999. "Price Stability and Full Employment as Complements in a New Europe: A Market-Based Price Stabilization Plicy for the New ECB," in Full Employment and Price Stability in a Global Economy, Paul Davidson and Jan A. Kregel, eds. Northampton, MA: Edward Elgar Publishing.

Lane, Robert E. 1991. The Market Experience. New York: Cambridge University Press.

Lane, Robert E. 2000. The Loss of Happiness in Market Democracies. New Haven: Yale University Press.

Lasch, Christopher. 1995. The Revolt of the Elites: and the Betrayal of Democracy. New York: W.W. Norton.

Leibenstein, Harvey. 1978. General X-Efficiency Theory and Economic Development. New York: Oxford University Press.

Lucas, Robert E., Jr., and Leonard A. Rapping. 1969. "Real Wages, Employment, and Inflation," Journal of Political Economy, 77: 721-54.

Marx, Karl. 1967. Capital: A Critique of Political Economy, vol. 1. New York: International Publishers. 
Marx, Karl. 1967. Capital, Vol. 3. New York: International Publishers.

Mazumder, Bhashkar. 2005. "Fortunate Sons: New Estimates of Intergenerational Mobility in the United States Using Social Security Earnings Data," Review of Economics and Statistics, 82 (2): $235-55$.

Minsky, Hyman. 1965. "The Role of Employment Policy," in Poverty in America, Margaret S. Gordon, ed. San Francisco: Chandler Publishing Co.

Minsky, Hyman. 1966. "Tight Full Employment: Let's Heat up the Economy," in Poverty American Style, Herman P. Miller, ed., Belmont, California: Wadsworth Publishing Co.

Minsky, Hyman. 1986. Stabilizing an Unstable Economy. New Haven: Yale University Press.

Lawrence Mishel, Jared Bernstein, Heidi Shierholz. 2009. The State of Working America: 20082009. Ithaca, N.Y. : ILR Press.

Mitchell, Wiliam, and L. Randall Wray. 2005. "In Defense of Employer of Last Resort: A Response to Malcolm Sawyer,” Journal of Economic Issues, 39 (1): 235-43.

Moyers, Bill. 2012. “Journal.” http://www.pbs.org/moyers/journal/04022010/profile3.html (Accessed 7-10-12).

Muller, Edward N. and Mitchell A. Seligson. 1987. "Inequality and Insurgency," The American Political Science Review, 81 (2): 425-52.

Offer, Avner. 2007. "The Challenge of Affluence," Interview, Challenge, 50 (2), March/April: 6-19.

Palley, Thomas I. 2001. “Government as Employer of Last Resort: Can it Work?” Industrial Relations Research Association, 53 ${ }^{\text {rd }}$ Annual Proceedings: 269-74.

Phillips, Kevin (interview). 2002. “Too Much Wealth, Too Little Democracy,” Challenge, September/October: 6-20.

Planet Ark. 2004. The Recycling Olympic Report. Sydney: Planet Ark Environmental Foundation.

Princen, Thomas. 2002. "The Shading and Distancing of Commerce: When Internalization Is Not Enough," in Confronting Consumption, Thomas Princen, Michael F. Maniates and Ken Conca, eds. Cambridge, MA: MIT Press, Ch. 5.

Raphael, Steven, and Rudolf Winter-Ebmer. 2001. "Identifying the Effect of Unemployment on Crime," Journal of Law and Economics, 44 (1): 259-83. 
Rose, Nancy E. 2012. "Bring Back the WPA: Lessons from the Job Creation Programs of the 1930s," in The Job Guarantee: Toward True Full Employment, Matthew Forstater and Michael Murray, eds. New York: Palgrave (forthcoming).

Sawyer, Malcolm. 2003. "Employer of Last Resort: Could It Deliver Full Employment and Price Stability?” Journal of Economic Issues, 37 (4): 881-907.

Sen, Amartya. 1997. “Inequality, Unemployment and Contemporary Europe," International Labour Review, 136 (2): 155-72).

Skidelsky, Robert. 2012. "Return to capitalism 'red in tooth and claw' spells economic madness," The Guardian, June 21. http://www.guardian.co.uk/business/economicsblog/2012/jun/21/capitalism-red-tooth-claw-keynes?newsfeed=true (Accessed 6-22-12).

Smith, Adam. 1762-63. Lectures on Jurisprudence, Oxford: Clarenden Press 1978.

Solnick, Sara. J. and David. Hemenway. 1998. "Is More Always Better? A Survey on Positional Concerns," Journal of Economic Behavior and Organization, 37: 373-83.

Solon, Gary. 1992. "Intergenerational Income Mobility in the United States," American Economic Review, 82 (3): 393-408.

Storm, Sara. 2003. "Unemployment and Families: A Review of Research," The Social Science Review, 77: 399-401.

Szasz, Andrew, and Michael Meuser. 1997. "Environmental Inequalities: Literature Review and Proposals for New Directions in Research and Theory," Current Sociology, 45, 3, July: 99-120.

U.S. Senate. 1961. Special Committee on Unemployment Problems, Readings in Unemployment, $86^{\text {th }}$ Cong., $1^{\text {st }}$ Sess. Washington, D. C.: U.S. GPO: 102.

Veblen, Thorstein. 1899. The Theory of the Leisure Class. New York: The Modern Library, 1934.

Veenhoven, Ruut. 1993. Happiness in Nations: Subjective Appreciation of Life in 56 Nations. Rotterdam: Erasmus University.

Vickrey, William S. 1992. "Chock-Full Employment without Increased Inflation," American Economic Review, 82 (2): 341-345.

Wade, Robert Hunter (interview with). "The American Empire," Challenge (January-February, 2004): 64-77

Wallich, Henry C. 1972. "Zero Growth,” Newsweek, 24, January. 
Wilkinson, Richard, and Kate Pickett. 2009. The Spirit Level: Why More Equal Societies Almost Always Do Better. London: Allen Lane.

Winkelman, L. and R. Winkelman. 1998. "Why are the Unemployed so Unhappy? Evidence from Panel Data," Economica, 65 (257): 1 - 15.

Wisman, Jon D. 2003. "The Scope and Promising Future of Social Economics." Review of Social Economy 61, 4: 425-45.

Wisman, Jon D. 2009. "Household Saving, Class Identity, and Conspicuous Consumption," Journal of Economic Issues, 63 (1): 89-114.

Wisman, Jon D. 2010. "The Moral Imperative and Social Rationality of Government-Guaranteed Employment and Reskilling," Review of Social Economy, 68 (1): 35-67.

Wisman, Jon D. and James F. Smith. 2011a. "Legitimating Inequality: Fooling Most of the People All of the Time," American Journal of Economics and Sociology, 70 (4): 974-1013.

Wisman, Jon D. 2011b. "Inequality, Social Respectability, Political Power, and Environmental Devastation,” Journal of Economic Issues, 45 (4): 877-900.

Wisman, Jon D. and Nicholas Reksten. 2012. "Rising Job Complexity and the Need for Government Guaranteed Work and Training," in The Job Guarantee: Toward True Full Employment, Matthew Forstater and Michael Murray, eds. New York: Palgrave (forthcoming).

Wolff, Edward N. 2010. "Recent trends in household wealth in the United States: Rising debt and the middle-class squeeze - an update to 2007," Working Paper No. 589. Annandale-onHudson, NY: The Levy Economics Institute of Bard College.

Wray, L. Randall. 1997. "Government of the Last Resort: Full Employment without Inflation." Jerome Levy Economics Institute, Working Paper 213.

Wray, L. Randall. 1998a. Understanding Modern Money: The Key to Full Employment and Price Stability. Northampton, MA: Elgar.

Wray, L. Randall. 1998b. "Zero Unemployment and Stable Prices," Journal of Economic Issues, 32 (2), June: 535-45.

Wray, L. Randall. 1999. "Public Service Employment-Assured Jobs Programs: Further Considerations," Journal of Economic Issues, 22 (2): 483-91.

Wray, Randall L. 2007. "The Employer of Last Resort Programme: Could It Work for Developing Countries?" Economic and Labour Market Papers. Geneva: International Labor Office, August. 
Wray, Randall, 2011. The Nation, June 27. http://www.thenation.com/article/161249/jobguarantee-government-plan-full-employment\# (Accessed 6-21-12). 